\title{
It's not me, it's you: law's performance anxiety over gender identity and cohabitation
}

\author{
Dr SARAh Beresford
}

University of Lancaster

\begin{abstract}
$\underline{\text { Abstract }}$
Legal discourse constructs "truths", not in relation to legal identity, but also in relation to other categories of identity. This article is concerned with a small but important part of those "truths" - that of correctly performed gender identity. It does so by exploring how some legal judgments determine the property interests of cohabiting couples in constructive trusts. However, this paper is not about constructive trusts as such. Rather, it is an interrogation of law's language which creates and perpetuates types of behaviour seen as legally relevant. It uses a Butlerian approach to offer an alternative way of conceptualising how an applicant seeking to establish a beneficial interest has to perform behaviours of a certain type (usually financial). Bringing a post-structuralist analysis to bear on this very traditional doctrinal area of law, the paper suggests that there is scope for legal discourse to re-evaluate what performances "count" when deciding upon proprietary interests.
\end{abstract}

Key words: gender, Judith Butler, constructive trusts, law

\section{Introduction}

$\mathrm{T}$ his paper is concerned with exploring how some of the legal constructions and performances of gendered identity come to exist within law. It will argue that law should recognise (more than it does presently), the plurality of the learnt nature of gender and its performativity. Although the subject matter I have chosen utilises constructive trusts, this paper is not about constructive trusts per se. There is a multitude of research covering this area of law and I do not intend to compete with it. ${ }^{1}$ Instead, I wish to offer a different perspective of this well-trodden path. I wish to apply Judith Butler's concept of gender performativity to argue that within this context, law continues to adhere to and perpetuate "appropriate" notions of gender identity performativity. In so doing, the paper explores the notion that law continues to use a process of normalisation of performativity to perpetuate certain established notions of femininity and masculinity, "revealing the implicit essentialism of normative judgments". ${ }^{2}$ In other words, law only recognises gender as it is normatively performed, and, as law repeatedly confirms these recognitions in individual cases, it is engaged in a performance of its own (i.e. of application of the principle of precedent) and in this way constructs not only the "truth" of law but reinforces also the

1 See, for example, A Bottomley, "Women and trust(s): portraying the family in the gallery of law" in S Bright and J Dewar (eds), Land Law: Themes and Perspectives (Oxford: OUP 1998), pp. 206-28.

2 V Munro and C F Stychin, Sexuality and The Law: Feminist engagements (London: Routledge-Cavendish 2007 ), p. 201. 
"truth" of gender performativity. This paper offers an interrogation of "law" and "the law" and examines some of the ways in which it continues to produce and regulate identities and the discourses that surround them.

\section{A brief overview of constructive trusts law}

A brief overview of some of the leading judgments in constructive cases will help to illustrate that performativity of so-called feminine (and therefore undervalued) behavioural traits, such as home-making, cooking, cleaning, nurturing, caring and child rearing, which when performed by women, is evidence of nothing at all; such activities have little, if any, probative force.

Even the black-letter lawyer would agree that only certain types of behaviour will be successful in creating and then enforcing beneficial proprietary interests. ${ }^{3}$ If the title deeds do not declare beneficial interests, an applicant has to show that they acquired an interest either from a resulting trust, a constructive trust or by proprietary estoppel. ${ }^{4}$ In constructive trusts, only financial behaviour or performance will be successful in establishing a property interest. ${ }^{5}$

There is no "clear and all embracing definition of a constructive trust" 6 and the meaning is "continually developing". 7 Despite the absence of a universally agreed definition of a constructive trust, they generally fall into one of two categories: firstly, where there is an express common intention which arises from an express (though informal) agreement, arrangement or understanding between the parties; and, secondly, where there is an inferred common intention, which will arise where one party has engaged in conduct referable to the acquisition of an interest in the property. ${ }^{8}$ In both cases, a constructive trust has always been seen as arising by way of operation of the law rather than the intentions of the parties. ${ }^{9}$ Interestingly, although the parties may "go to the law" to have their dispute settled, it will be equity which determines the outcome. Although the common law is considered to be masculine, equity is considered feminine. Ironically, despite the perception that equity is feminine, it still embodies the masculine normative values of gender performativity used by a judiciary "educated and embodied in ways that make them deaf to the pleadings of "the other', the woman". 10

Within the context of cohabitation disputes, the ongoing existence of this requirement continues to privilege financial behaviour and excludes those individuals who have never made (or made very little) direct financial contributions. When Butler argues that gender is

3 Married couples are dealt with under Matrimonial Causes Act 1973 and civil partners under the Civil Partnership Act 2005 .

4 Hayton has argued that it is possible for a claimant to bring a claim under proprietary estoppel, although there has been debate about whether there is indeed a difference between a constructive trust and proprietary estoppel, or whether the difference is merely illusory, see D Hayton, "Equitable rights of cohabitees" (1990) Conv 370, p. 380

5 Trusts of Land and Appointment of Trustees Act 1996.

6 Carl Zeiss v Herbert Smith and Co. No 2 (1969) 2 Ch 276, CA, per Edmund-Davies, at p. 300.

7 J McGhee and H Turner, Snell's Equity, 31st edn (London: Thomson, Sweet \& Maxwell 2000), p 192.

8 Law Commission, Cobabitation: The financial consequences of relationship breakdown No $307 \mathrm{Cm} 7182$ (Norwich: TSO 2007).

9 S Wong, "Constructive trusts over the family home: lessons to be learned from other Commonwealth jurisdictions?” (1998) 18(3) Legal Studies 369-90, p. 370.

10 P Pether, "Measured judgments: histories, pedagogies, and the possibility of equity" (2002) 14(3) Law and Literature 519. See also R Mackenzie, who has suggested that equity "is frequently marginalised as elusive, uncertain, irrational, subjective, quintessentially feminine". This is in contrast to a common law which is "purportedly authoritative as precedent-based, rational, objective and certain": R Mackenzie, "Beauty and the beastly bank: what should equity's fairy wand do?" in A Bottomley (ed.), Feminist Perspectives on the Foundational Subjects of Law (London: Routledge-Cavendish 1996). 
a "set of repeated acts .... that congeal over time to produce the meaning of substance, of a natural sort of being", 11 her analysis can be applied to law, allowing us to view law as a set of repeated stylised acts; a set of repeated performances which lawyers call the common law of precedent. It follows, therefore, that the authority and force of judgments rest upon the repeated performances of previous judgments. In the light of this, it might be helpful to briefly examine some of the leading cases decided since the 1970 s.

Arguably, any examination of the doctrine of constructive trusts should perhaps, start with the case of Gissing v Gissing. Mrs Gissing had been married to Mr Gissing for 16 years and had paid substantial sums towards the upkeep of the house, but the house had been conveyed into the sole name of Mr Gissing. Mrs Gissing had made no direct contributions towards its purchase. On their divorce, she attempted to claim a beneficial interest.

Lord Diplock held that in the absence of direct financial contributions to the purchase price, and where the legal title to a property was owned by one person, cohabitees could only successfully claim a beneficial interest in the property if they could provide evidence that both cohabitees had a common intention that the beneficial interest would be shared. In addition, it also had to be evidenced that the legal owner had induced the beneficiary to act to their own detriment in reliance of this agreement. Lord Diplock explained it thus:

[A trust] is created ... whenever the trustee has so conducted himself that it would be inequitable to allow him to deny to the cestui que trust a beneficial interest in the land acquired. And he will be held so to have conducted himself if by his words or conduct he has induced the cestui que trust to act to his own detriment in the reasonable belief that by so acting he was acquiring a beneficial interest in the land. ${ }^{12}$ (emphasis added)

Performativity in the guise of "behaviour", "conduct" and "acting" were clearly types of behaviours important to the court here. The court held (unanimously) that there was no beneficial interest acquired here by the wife, firstly, because she had made no financial contribution to the purchase price of the property and, secondly, because she had failed to establish the necessary common intention. Thus, her behaviour, her conduct and her acts were not deemed to be legally relevant, whereas the conduct, behaviour and acts of $\mathrm{Mr}$ Gissing were. Judgments that only recognise certain types of behavioural function and commitment became a pattern throughout subsequent cases. Eves $\mathrm{v}$ Eves $^{13}$ is another example. This case is often used to illustrate the (mistaken) understanding that non-financial conduct can establish a beneficial interest. In Eves $\mathrm{v}$ Eves, the court was more concerned that an errant husband should not be allowed to benefit from dishonesty, than they were with ensuring a wide interpretation of what kind of behaviour "counts". Janet and Stuart Eves had lived together for four years during which time a house had been paid for by and conveyed into Stuart Eves' sole name. Janet Eves had been explicitly led by Stuart Eves to believe when they set up home together that the property would belong to them jointly and that the only reason the legal title was vested solely in his name was because she was then under 21 . She later moved out of the house with the children and claimed a beneficial interest. The Court of Appeal imposed a constructive trust on the house and awarded her a quarter share.

Janet Eves' conduct and behaviour were not considered legally relevant (she had undertaken redecoration, demolition of a garden shed, used a 14-pound sledgehammer to break up an area of concrete at the front of the house and, of course, been in an intimate cohabiting relationship for four years). Again, similar to Gissing v Gissing, Janet Eves'

11 J Butler, Gender Trouble: Feminism and the Subversion of Identity (New York: Routledge 1990), p. 31.

12 [1971] AC 886, per Diplock, p. 905B-C

13 [1975] 1 WLR 1338. 
performativity of her gender - her acts, her conduct - were not legally relevant to the court. Ironically, it was the dishonest behaviour of Stuart Eves in misrepresenting the age requirement which influenced the court's decision. However, future cases mistakenly relied on this aspect in the hope of demonstrating that physical labour counts.

Arguably, one of the most infamous cases in this area of law is still Burns $\mathrm{v}$ Burns. ${ }^{14}$ The performance of the so-called feminine behaviour of looking after the home and the children was not enough to support the necessary inference of common intention. The facts are well known: the couple had cohabited for 19 years, 17 of those years in their home which was registered in his sole name. She made no financial contribution to the purchase price or subsequent mortgage. Valerie Burns' behaviour was constituted by being in an intimate relationship for 19 years, looking after the home and having primary responsibility for raising the couple's two children. Valerie Burns had not been able to undertake paid employment due to her domestic responsibilities and, in the few times when she had had some income, she had used the money for the children or family expenses. ${ }^{15}$ It was held that she was not entitled to a beneficial interest in the property - her behaviour had not been sufficiently financial. Valerie Burns' performatively constituted gender role meant that she did not behave "correctly". The failure of the court to recognise her contribution was due to the courts' inability to recognise behaviour and conduct that was other than financial.

These early examples clearly demonstrate that performativity of so-called feminine traits was of no legal interest to the courts. Relying as they do on the repeated set of stylised acts of precedent, it is no surprise that the later cases are no different. For example, in James $\mathrm{v}$ Thomas, the Court of Appeal gave some interesting comments on what kinds of behaviour and words might be capable of giving rise to a constructive trust. The leading judgment (given by Sir John Chadwick) stated that the couple had lived together "as husband and wife" for 15 years (emphasis added). The use of the word "as" in that sentence raises an issue of performativity. Chadwick stated that the woman's evidence "as to which there was no real dispute ... was that she drove a tipper, dug trenches, picked up materials, laid concrete, tarmac and gravel and generally undertook (alongside Mr Thomas) the manual work associated with a business of that nature". 16

In fact, in relation to Ms James' improvement of the property, Chadwick refers to "the near Herculean labours of the Claimant". ${ }^{17}$ Despite this, however, the work that she had done did not, according to the court give rise to the necessary "detrimental reliance". Her behaviour did not count because "in the absence of an express post-acquisition agreement, a court will be slow to infer from conduct alone that parties intended to vary existing beneficial interests established at the time of acquisition"18 (emphasis added). Indeed, Chadwick was firmly of the opinion that what Ms James was doing gave rise "to no inference that the parties had agreed (or had reached a common understanding) that she was to have a share in the property: what she was doing was wholly explicable on other grounds". 19 The "other grounds" were because "she and Mr Thomas were making their life together as man and wife", the clear implication being here that it was not financial self-interest, but for reasons

14 [1984] 1 All ER 244.

15 A Bottomley, "From Mrs Burns to Mrs Oxley: do co-habiting women (still) need marriage law?" (2006) 14(2) Feminist Legal Studies 181-211.

16 [2007] EWCA Civ 1212, per Chadwick, at para. 4.

17 Ibid. para. 11.

18 Ibid. para. 24.

19 Ibid. para. 27. 
of love and affection. ${ }^{20}$ It is also clear from reading Chadwick's judgment that there was only one way to interpret the words and conduct:

Nor, as it seems to me, can it be said that the observation "this will benefit us both", when made in the context of a discussion of matters relating to the business, was intended or understood to be a promise of some property interest in The Cottage. Given that the outgoings of both parties were funded by the receipts of the business - and that, from about 1999, the business was carried on in partnership - there is no reason to think that the observation "this will benefit us both" (in relation to the business) was more than a statement of the obvious: what was of benefit to the business was of benefit to both Mr Thomas and Miss James, for whom the business was their livelihood. ${ }^{21}$ (emphasis added)

It is clear from this passage that, according to the judge, there was only one possible interpretation of behaviour - it was "obvious". The physical labour was not considered legally relevant. What was considered relevant was the conversation which included the sentence "this will benefit us both". The judge was of the opinion that there was only one possible interpretation of this sentence. I strongly disagree with Chadwick's opinion that there is only one way to interpret the words "this will benefit us both". These words are capable of more than one, if not multiple, interpretations. Chadwick's pronouncement that there's only one interpretation exemplifies law's idea that conduct is always gender neutral. I would suggest that this assumption demonstrates an andocentric approach to the interpretations given to conduct and behaviour, and that conduct, like identity, is performatively constructed. Chadwick took these words to mean relating only to the business the couple owned, but they are equally capable of relating to the relationship between the couple themselves. If we apply some of the work undertaken by Miles, ${ }^{22}$ Douglas and Woodward, it is reasonable to put forward the premise that the couples' understanding of the basis of their relationship was fundamentally at odds with each other. Further, the masculine nature of law failed in this instance to comprehend the woman's approach to justice. The meaning(s) and importance ascribed to being in an intimate relationship per se - doing "herculean" physical labour, working without pay with one's partner - are thus likely to be different depending upon whether one is performing femininity or masculinity.

\section{Conduct clearly counts}

It is clear therefore, that conduct and performance are the benchmark for the determination of beneficial interests. However, whilst this might appear to be an objective requirement and that there is some tacit acknowledgment that conduct can be constituted by words and conduct, this is still predicated upon financial behaviour. Thus, "the determination of beneficial interests is evidenced by what the parties said and did at the time of the acquisition" 23 (emphasis added). Indeed, various Law Commission reports have recognised that conduct counts. In its 2002 report, the Commission suggested that conduct was an important indicator in relation to the question of quantification of beneficial entitlement and that a survey of the whole undertaking between the parties should be undertaken which

20 [2007] EWCA Civ 1212, para. 36. See also S Greer, "Back to the bad old days?" (2008) 158 NLJ, issue 7306.

21 At para. 34.

22 See, for example, J Miles "Property law v family law: resolving the problems of family property" (2003) 23 Legal Studies 624-48; and also G Douglas, J Pearce and H Woodward, "A failure of trust: resolving property disputes on cohabitation breakdown” (2007) www.bris.ac.uk/law/research/centres-themes/cohabit/cohabitrep.pdf (last accessed 2 June 2012).

23 Oxley v Hiscock per Chadwick LJ, at para. 69. 
should take into account "all conduct which throws light on the question of what shares were intended"24 (emphasis added).

The Law Commission in 2006 recommended that some couples should obtain beneficial interests where they could demonstrate "qualifying contributions to the relationship giving rise to certain enduring consequences at the point of separation". ${ }^{25}$ The next, obvious questions are: what is understood by a "qualifying contribution" and how does someone "establish" this? What particular methodology has been chosen to arrive at a determination of what counts and what does not count? The Commission states that a qualifying contribution is:

[A]ny contribution arising from the cohabiting relationship which is made to the parties' shared lives or to the welfare of members of their families. Contributions are not limited to financial contributions, and include future contributions, in particular to the care of the parties' children following separation. ${ }^{26}$

Clearly, one of the Commission's concerns in 2006 was to make provision for any children of a cohabiting relationship. More precise examples of what constitutes qualifying contributions include: care for children of both parties, both during and after the relationship; care for other members of their families, including children who are not children of both parties and elderly relatives; financial support of the family; activities (whether financial or non-financial) which enhance the value of, or enable the respondent to acquire or retain, capital assets, including savings and investments; unpaid work in the respondent's business; funding professional and other training; and giving up secure accommodation in order to commence cohabitation. ${ }^{27}$ In a limited way, these proposals are almost undoubtedly an improvement upon what already exists. However, it is extremely doubtful whether the ambit of what behaviour counts is capable of being drawn much more widely than is the case currently. Even if the Law Commission had been able to include a much wider range of legally relevant behaviours, it would not matter much if the parties themselves continue to repeat their gendered performances. The Commission was at pains to stress in its report that:

[F]inancial relief should not be available simply because an applicant could establish that he or she made a qualifying contribution. Qualifying contributions would only give rise to relief where they had resulted in a retained benefit or an economic disadvantage. For example, carrying out routine maintenance work on property in one's spare time, without adding to its value, would not give rise to relief. Nor would buying groceries where the respondent was able to pay the mortgage without that contribution being made. ${ }^{28}$

I would suggest that both "routine maintenance work" and "buying groceries" have an easily identifiable financial cost. Further, it is possible that such behaviour could be viewed by some individuals as "evidence" of their emotional commitment and intimacy. It is well documented that there are gendered differences in the ways in which men and women view domestic labour within the household with studies consistently showing that:

Women, even those who work outside the home full-time, retain the bulk of responsibility for organising and performing domestic labour including child care. Although many studies reveal that men are increasing the amount of work

24 Law Commission, Sharing Homes No 287 (Norwich: TSO 2002), para. 4.27.

25 Law Commission, Cohabitation, n. 8 above.

26 Ibid. para. 4.34.

27 Ibid. para. 4.44.

28 Ibid. para. 4.45 . 
they do in the home, their contribution still falls well short of what would be needed to make the division equal. ${ }^{29}$

The performance of femininity and masculinity could arguably "cause" men and women to vary in their experiences and expressions of intimacy in relationships resulting in men viewing and valuing certain types of behaviour differently to how women might view and value certain behaviours. ${ }^{30}$ However, given its specific exclusion in the Law Commission's report, it clearly does not desire or envisage such behaviour as being legally relevant, presumably because such contributions could be seen as common incidences of house-sharing (such as flatmates) and not necessarily exclusive to intimate relationships. However, whilst there may be instances where it might be problematic to determine where flatmates end and couples in an intimate relationship begin; it is unarguable that there are significant, fundamental and legally relevant differences between the two. Indeed, the Law Commission expressly acknowledged that "intimate" relationships bore the "hallmarks of intimacy and exclusivity, giving rise to mutual trust and confidence between Partners". 31 There are further disadvantages with the commission's proposals in terms of how someone "establishes" a qualifying contribution. What is clear is that past contributions resulting in economic disadvantage would still have to be "proved" in evidential terms. As pointed out by Douglas et al., this could produce "the same kinds of disputes and difficulties over the evidence that trusts Law currently generates". 32 The Law Commission's 2006 report heavily influenced the outcome of the case of Stack $\mathrm{v}$ Dowden ${ }^{33}$ which arguably goes partway to ameliorating some of the harshness of Lloyds Bank v Rosset. ${ }^{34}$ Hale suggests that Rosset had set the hurdle for a constructive trust "rather too high". In Stack v Dowden, the House of Lords held that the beneficial ownership of a house should ordinarily follow the legal ownership. Thus, where a property is in joint names and there is no express declaration of trust, there is a presumption that the beneficial interest is held in equal shares. Hale was insistent that the parties' conduct be taken into consideration because:

The Law has indeed moved on in response to changing social and economic conditions. The search is to ascertain the parties' shared intentions, actual, inferred or imputed, with respect to the property in the light of their whole course of conduct in relation to it. ${ }^{35}$ (emphasis added)

In Stack v Dowden, Hale was at pains to stress the "holistic" approach taken by the Law Commission in 2006. At first glance this, and Hale's emphasis upon the parties' conduct is to be welcomed. However, it is still the case that the ambit of conduct in question continues to be narrowly drawn. Firstly, Stack v Dowden is only of use in situations where the property is vested in joint names. Where only one of the parties owns legal title to the property, sole beneficial ownership is still the starting point. Yet again, it would appear that performativity is called for as the onus falls on the other party to show a beneficial interest in the property and this can only be done by demonstrating a certain type of conduct. Stack v Dowden was discussed at length in the recent Supreme Court decision of Jones v Kernott, ${ }^{36}$ where Hale (in

29 A Diduck and F Kaganas, Family Law, Gender and the State 2nd edn (Oxford: Hart 2006), p. 194.

30 See, for example, M Hook et al., "How close are we? Measuring intimacy and examining gender differences" (2003) 18(4) Journal of Counselling and Development 462-72; see also J Ridley, "Gender and couples: do men and women seek different kinds of intimacy?”(1993) 8(3) Sexual and Relationship Therapy 243-53.

31 Law Commission, Sharing Homes, n. 24 above, para. 3.6.

32 Douglas et al., "A failure of trust", n. 22 above, p. 144.

33 [2007] UKHL 17.

34 [1991] 1 AC 107.

35 Stack v Dowden [2007] UKHL 17, per Hale, para. 60.

36 [2011] UKSC 53. 
particular) attempted to clarify her leading judgment in Stack v Dowden. The Supreme Court in Jones $\mathrm{v}$ Kernott re-iterated constructive trust orthodoxy by stating that the fact that "where a family home is bought in ... joint names .... the starting point is that equity follows the law and they are joint tenants both in law and in equity". ${ }^{37}$ In this respect, the judgment does not say anything new. However, Hale did state that this presumption can be rebutted by evidence that it "ceased to be, the common intention of the parties to hold the property jointly". 38 Again, however, this is nothing new - law is still concerned with "common intention". If we are concerned with asking how law arrives at "legally relevant behaviour", we need to know what the Supreme Court in this instance understands by the term "common intention". I would suggest that Hale has usually advanced the jurisprudence in this area by stating that the parties" "common intention is to be deduced from their conduct". ${ }^{39}$ Indeed, the court went so far as to suggest that although financial contributions should still be considered relevant "there are many other factors which may enable the court to decide what shares were either intended or fair". ${ }^{40}$ However, the judgment further states that the couples' "common intention is to be deduced objectively from their conduct". However, it is clear from what has been discussed above that one person's objectivity is another person's subjectivity.

Despite such "progress", however, Lloyd's Bank v Rosset is still regarded as a leading case in this area. Rosset re-affirmed the principle that financial performativity is what the courts are most interested in ascertaining. In so doing, the House of Lords failed to acknowledge the importance of the performance of gender roles and, indeed, that gender itself is normatively performed. Importantly, Bridge LJ, in giving the leading judgment, was insistent that in the absence of some express agreement, discussion or understanding between the parties, even substantial unpaid labour would not give rise to the necessary intention and he was "extremely doubtful whether anything less [than a direct financial contribution] will do". ${ }^{4}$

The Rosset judgment underlines a continuing intense preoccupation with financial performativity. Given that masculinity and femininity are capable of being performed differently to each other, this requirement privileges masculine performativity.

At the risk of stating the obvious, it still remains the case that we are dealing here with personal and intimate relationships not business relationships; couples "deal with each other more by trust and collaboration than by organised thinking about their respective rights". 42 Despite the increase in the popularity of cohabitation agreements, it is still comparatively rare for couples to draw up cohabitation agreements and/or declarations of trust. ${ }^{43}$ Reliable figures as to how many cohabiting couples enter into cohabitation agreements are hard to come by, but over half of those surveyed in the 2000 British Social Attitudes Survey incorrectly believed that cohabitants have a "common law marriage" giving them the same legal rights as married couples. ${ }^{44}$ The 2001 census shows there were 2 million cohabiting couples in England and Wales in 2001, an increase of 67 per cent on the figures from the 1991

37 Jones v Kernott [2011] UKSC 53, per Hale, para. 51.

38 Ibid. para. 51.

39 Ibid. para. 51.

40 Ibid. para. 51.

41 Bridge LJ, p. 1117.

42 A Barlow and C Lind, "A matter of trust: the allocation of rights in the family home" (1999) 19(4) Legal Studies 473.

43 Actual take-up figures are difficult to come by although there seems to be a proliferation of companies offering cohabitation agreements - even Tesco has got in on the act and offers a Cohabitation Agreement Form Pack for $£^{4.39}$.

44 A Barlow et al., "Family affairs: cohabitation, marriage and the law" (London: Nuffield Foundation 2002). See also R Probert, "Why couples still believe in common-law marriage" (2007) 37 Family Law 403. 
census. The number of cohabiting couples in England and Wales is expected to rise from 2.25 million in 2007 to 3.7 million in $2031 .{ }^{45}$ Even at a brief glance therefore, these figures tell us that there are a significant number of people who will not be seeking a cohabitation agreement or something similar. Yet is seems that this is what the courts are implicitly looking for. Legal discourse continues to expect that the parties' rights will be determined according to their common intention - a matter they will rarely have thought it necessary to consider.

Despite attempts at reform in this area, the language of law continues to operate on the presumptive level of financial contributions and behaviour. The most recent statutory attempts at reforming the law of cohabitation still deny the existence of gendered difference. Lord Lester's unsuccessful Cohabitation Bill 2008 contained a proposal (clause 9) similar to s. 25 of the Matrimonial Causes Act 1973. Clause 9 would have directed the courts to test the couple's "degree of commitment" in deciding beneficial interests. This was, however, just another test of performativity not guaranteed to be free from preconceived ideas of the masculine and feminine and the possibility of gendered differences of perceptions of commitment. In addition to the welfare of any relevant child, the matters to be considered by the court included the contributions each party had made to the relationship in financial terms. There was to have been no presumption of equal sharing of property. The Bill received a second reading in the House of Lords on 13 March 2009 , but failed to proceed any further having run out of parliamentary time. Another Private Members' Bill, introduced in March 2009 also failed to proceed. ${ }^{46}$ In 2002, the Law Society had stepped into the fray with its report on cohabitation, ${ }^{47}$ which placed its focus upon cohabitation, not just on property issues. ${ }^{48}$

\section{Various solutions offered}

There has been extensive research relating to the question of how the law does and should deal with property division upon the separation of cohabitants. Miles, for example, has provided a useful analysis of the conceptual boundaries of this debate by exploring the doctrinal differences between the approach taken by family law and the approach taken by property law associated with people who share homes. ${ }^{49}$ Miles' work usefully identifies some of the myriad of problems associated with reform in this troublesome area of law, but in particular suggests that these problems cannot be solved "without express reference to the nature or effects of the relationship between the parties and an express policy aimed at dealing specifically with the problems encountered in such relationships". 50 What should underline any approach, therefore, is not necessarily an examination of the law per se, but also an examination of the basis upon which couples understand their relationship. Barlow has explored how law is responding (or not), to the trends of family restructuring away from marriage in the UK and the rest of Europe. ${ }^{51}$ Barlow identifies the UK legal responses to cohabitation as being developed on an "ad hoc basis leaving the law complex, confusing and often illogical". 52 Barlow argues for a methodological approach that allows for an examination of both "form" and "function" of the particular familial relationship, ${ }^{53}$

45 Office for National Statistics, Social Trends (London: ONS 2009), p. 8.

46 Cohabitation (No 2) Bill 2008-2009.

47 Law Society, Cohabitation: The case for clear law (London: Law Society 2002).

48 Cited in S Wong, "Would you 'care' to share your home?” (2007) 58 NILQ 1.

49 Miles, "Property law v family law", n. 22 above.

50 Ibid. p. 648.

51 A Barlow, "Regulation of cohabitation, changing family policies and social attitudes: a discussion of Britain within Europe" (2004) 26(1) Law and Policy 57-86.

52 Ibid. p. 60.

53 Barlow, "Regulation of cohabitation", n. 51 above, p. 78. 
which would help to provide a "plurality of legal regulative structures" in response to diverse family forms. The extensive research undertaken by Douglas and Woodward clearly exposes the tensions between cohabitants' expectations and legal positions. ${ }^{54}$ One of their key findings identifies the extreme mismatch between cohabitants' perception of issues over property they have with their partners and the legal view. This mismatch extends far beyond matters of interpretation, practice and procedure and is so severe that: "The redefinition of their issues into legal concepts may bear little relation to the categories as perceived from the perspective of cohabitants." 55

Barlow and Lind usefully suggest that the way forward in this area is legislative reform which has the best chance of being able to ensure that "intimacy, trust and collaboration are significant features in the legal concept of "family". 56 The authors explore several different methods in which this might be achieved, but arguably the most convincing of these is the idea that there should be a legal presumption of joint ownership of the family home. ${ }^{57}$ On the face of it, this is an attractive idea. However, of concern is the fact that it is based upon the idea that all cohabitating relationships can, and should, be "treated alike". 58 The basis of Barlow and Lind's argument is that it "looks to the degree of commitment that relationships demonstrate". ${ }^{59}$ Whether an applicant can demonstrate the necessary "degree of commitment" would be necessarily contingent upon subjectively assessed factors. There is of course no guarantee that a court will interpret the phrase "degree of commitment" to specifically include the differences between the performativity of femininity and masculinity.

Thus, despite some of the excellent work that has been undertaken in this area of law over the years, the operation of constructive trusts is still reliant upon a certain type of behaviour. I do not dispute the principle of behaviour, what I do dispute is the type of behaviour that "counts" or is considered legally relevant evidence to intention. I suggest that what constitutes legally relevant evidence is a matter of subjective interpretation. That which constitutes legally relevant behaviour is not the result of applying objective criteria, but rather, it is arrived at as a result of subjectively constituted notions of the norms of gendered performativity. Thus, it is not just the behaviour of individuals within a cohabiting relationship which should be subject to interrogation, but also the performativity of law and legal discourse.

\section{Applying Butler to constructive trusts}

The application of a Butlerian methodology suggests that much of law's authority and legitimacy comes in the form of repetition. Thus, the importance of common law's reliance on previous cases cannot be underestimated: "If the common Law judgment is accepted as correct, it will be instantiated within the legal system as a general rule properly applicable to a range of similar or analogous circumstances." 60

A Butlerian analysis allows for an interpretation of legal judgments which can be regarded as a "set of repeated performances" constituting a discursive body of knowledge. These repeated performances purport to constitute a (singular) "truth" - "the law" on any

54 Douglas et al., "A failure of trust", n. 22 above.

55 Ibid. p. 77.

56 Barlow and Lind, "A matter of trust", n, 42 above.

57 Ibid. p. 478.

58 Ibid. p. 487.

59 Ibid. p. 487.

60 D E Edlin, Common Law Theory, Cambridge Studies in Philosophy and Law (Cambridge: CUP 2007), "Introduction". 
issue - such as, in our context, that there is only one way to constitute legally relevant evidence of behaviour and that that way is financial. This arguably raises the question of what comes first - does law reflect gender norms or does it construct and impose them? Butler might answer this question by suggesting that there was "no beginning" as such, only a "repeated set of acts". I would go further and argue that the discourse of law, as a part of the society in which it is situated, reflects, constructs and imposes gender norms. Thus, it would be misleading to ask "Which comes first: law or society?" when, in fact, neither can exist without the other. The question should be: how do law and society interact to produce truth and knowledge?

The cohabitation cases clearly demonstrate that law fails to recognise the contingent aspects of these truths and the resultant categories of legal relevance. Butler's work also allows for an acknowledgment of the contingent nature of the truths that performativity purports to create. In the context of constructive trusts, the contested and contingent categories include "woman", "man", "conduct" and "relationship". These categories are used by legal discourse in essentialist ways. Butler has argued that some aspects of feminism had made a mistake by using essentialist ideas in trying to assert that "women" were a group with common characteristics and interests. This approach had the disadvantage of reinforcing a binary view of gender relations in which human beings are divided into two clear-cut groups, women and men. Women should not be viewed as a unified homogenous group as the "very subject of women is no longer understood in stable or abiding terms". 61 Butler's theories have the potential to allow for the rejection of such essentialist constructs as the antitheses to the potential fluidity of the categories mentioned above. Such an approach provides therefore for a site of resistance to the idea that women and men behave in certain ways due to biological essentialism and provides instead for the opening up of spaces allowing for the idea that individuals behave in certain ways because they are performing their gender.

Butler first suggested the idea that gender is performatively constructed in Gender Trouble, arguing that conduct is performatively constituted - it is the repeated performances of a certain type of behaviour which lead to it being (mistakenly) regarded as "natural" or "innate":

Gender is the repeated stylisation of the body, a set of repeated acts within a highly rigid regulatory frame that congeal overtime to produce the appearance of substance, of a natural sort of being. A political genealogy of gender ontologies, if it successful, will deconstruct the substantive appearance of gender into its constitutive acts and locate and account for those acts within the compulsory frames set by the various forces that police the social appearance of gender. ${ }^{62}$

Thus, gender is not something a person $i$, rather it is something a person does - an act, or a series of repeated acts. A person's gender therefore can be viewed as a verb rather than a noun, a "doing" rather than a "being". 63 These performances and repeated acts and behaviours take place within different discourses, including the "highly rigid regulatory frame" of legal discourse. A Butlerian analysis of law suggests therefore that, although both a man and a woman demonstrate legally recognised relevant masculine and feminine behaviour repeatedly, they do so differently. Thus, as usefully pointed out by Scott-Hunt and Lim, the legally recognised behaviour repeatedly "heard" or "understood" by law is that of the masculine identity:

One important reason why equity rarely embodies women's points of view is precisely because there is often no place for them within law and the legal

61 Butler, Gender Trouble, n. 11 above, p. 1.

62 Ibid. pp. 40-4.

63 Ibid. p. 25. 
process to be heard or because, if heard, they are not understood. The sorry saga of disputes over the family home in English trust law is a classic instance of judges operating entirely within the equitable domain, but failing to hear the woman's point of view or to comprehend her approach to justice. ${ }^{64}$

The judges can't "hear" or "comprehend" because in most cases, the women are performing their femininity as expected. As pointed out by Smart, the discourse of law insists on a "rigid distinction between male and female, masculine and feminine, insisting that certain attributes follow this biological distinction". 65 It is conceivable that the performance of gendered identities leads women and men to use language differently thereby creating different expectations within a relationship. ${ }^{66}$ Arguably, cohabitants may have differing perceptions about what "commitment" means in their relationships. Deech points out that:

Cohabitants have different perceptions about their commitment to each other. In particular, the man normally does not accept commitment until he has made a clear decision about their future together, whereas the woman will see it in her moving in. ${ }^{67}$

There has been some important work, particularly feminist work, carried out over the years in this field suggesting that there are indeed identifiable differences between the performance of femininity and the performance of masculinity. Work undertaken by Bottomley in this area usefully exposes that the potential conflict between men and women may well be due to a "narrative of differing expectations". 68

For example, Gilligan's important analysis in the early 1980s opened up the possibility that men and women use language differently, to communicate different things. Gilligan argued that women are more likely to voice their concerns in terms of conflicting responsibilities and their effect on relationships with others, while men are more likely to view the world in terms of hierarchical principles that determine what is right and wrong. Thus, "the way people talk about their lives is significant, the language they use and the connections they make reveal the world that they see and in which they act". ${ }^{69}$

Tannen writing in the early 1990s, argued that gender differences are parallel to crosscultural differences. ${ }^{70}$ Tannen explored the notion that, when interpreting the cultural information encoded by language, men and women rely on different subcultural norms. Female subculture uses language to build equal relationships, while male subculture uses language to build hierarchical relationships. Tannen's research opened the door to the possibility that women place more attention and importance on underlying meanings about intimacy. Conversely, men, to a greater extent than women, are more sensitive to "between the lines meanings" about status. Oropesa, writing in 1996, took this slightly further arguing that responses given to questions about attitudes to cohabitation demonstrate that individuals can have internalised norms about appropriate and "normal" behaviour with

64 S Scott-Hunt and H Lim, Feminist Perspectives on Equity and Trusts (London: Cavendish 2001), p. 10.

65 C Smart, Law, Crime and Sexuality: Essays in feminism (London: Sage 1995), p. 219.

66 R Lakoff, Language and Women's Place (New York: Harper \& Row 1975).

67 Baroness Deech, 13 March 2009, HL debs, col. 1419, Cohabitation Bill Second Reading. Deech was speaking against legal recognition of cohabiting relationships - a position she has taken for some considerable time. See, for example, her article "The case against legal recognition of cohabitation" (1980) 29 International and Comparative Law Quarterly 480.

68 A Bottomley, "Self and subjectivities: languages of claim in property law" (1993) 20(1) Journal of Law and Society 60-1.

69 C Gilligan, In a Different Voice (Cambridge MA: Harvard UP 1982).

70 D Tannen, You Just Don't Understand: Women and men in conversation (New York: Morrow 1990). 
respect to their cohabiting relationship. ${ }^{71}$ More recent work, such as that of Skeggs, usefully draws out that law places values on the behaviour of an individual in an intimate relationship: "explicit quantification of value still takes place in Law where the 'proper' of an intimate relationship is adjudicated". ${ }^{72}$

The research into the use of language briefly outlined above facilitates a different interpretation of words and actions in relation to property disputes between cohabitating couples. It allows us to acknowledge the possibility that conversations between men and women have significance and meaning attached to say "moving in together". These actions can mean different things according to whether one is a man or woman or, using Butler's argument, dependent on whether one is performing one's masculinity or femininity. However, the range of possible responses, meanings and interpretations are not acknowledged by law, which continues to advance one singular interpretation of behaviour and conduct in intimate relationships. It is, arguably, masculinised behaviour that privileges and interprets financial behaviour as legally relevant.

\section{Some conclusions}

It would appear then that legal judgments continue to construct not only the truth of law but also continue to reinforce the truth of correctly performed masculinity/femininity. If so, reforms of the law based on family function or measures of commitment won't, on their own, make any significant difference to constructive trusts because both function and commitment are still comprehended only in gendered terms and will continue to be performed by law in the same old ways. However, viewing what is going on through the performativity lens also means that there is room for resistance. Because truth or identity is always being performed/constructed/reconstructed, it can be performed differently, opening up space to understand it differently. Law, for example, does depart from precedent occasionally, so there is the possibility that legal truth can come to look different. Similarly, gender performance can shift, so ideas of proper wifehood/husbandhood/demonstrations of commitment/intention are not fixed. However, two things need to happen simultaneously: firstly, space needs to open up within legal discourse to "test" differently for functionality or commitment and, secondly, men and women need to begin to "do" intimacy/commitment/cohabitation differently. Unless these two things happen, nothing much will change. If we want to stay within law's rules of intention, detriment, etc., we need law to understand evidence of intention to share outside of currently performatively constructed gendered rationalities.

Given that constructive trusts are "imposed by equity in order to satisfy the demands of justice and good conscience", 73 it is a source of continuing disappointment that they fail to do so in many cases. It is clear that "particularly in cohabitants" cases, the courts seem to continue to attach substantial weight to the parties' respective financial contributions". 74 Cases such as Stack v Dowden and Oxley v Hiscock clearly illustrate that parties' non-financial contributions get little if any mention during the court's deliberations on quantification. ${ }^{75}$

Law should take the opportunity to re-examine at a fundamental level what "counts" as legally relevant behaviour and resist the temptation to adhere to the current persistent and

71 R S Oropesa, "Normative beliefs about marriage and cohabitation: a comparison of non-Latino whites, Mexican Americans and Puerto Ricans" (1996) 58(1) Journal of Marriage and Family 49-62.

72 B Skeggs, "The value of relationships: affective scenes and emotional performances" (2010) 18 Feminist Legal Studies 29-51, p. 38.

73 McGhee and Turner, Snell's Equity, n. 7 above, p. 192.

74 Law Commission, Cohabitation, n. 8 above, p. 79.

75 Ibid. 
performatively constructed overly narrow, rigid idea of legally relevant behaviour. The discourse of law continues to expect individuals to perform their gender roles in the expected way, but only rewards a narrow range of legally recognised behaviour performances. Individuals who are seeking to gain a proprietary interest have little immediate choice but to perform the gender identity expected of them notwithstanding that this is a reflection of law's discourse, not an identity of their own making - as Butler states, the subject is "led to embrace the terms that injure me because they constitute me socially". 76 The ways in which law and society continue to perceive gender roles arguably lies at the very root of inequality of the sexes. If we deconstruct socio-legal views of gender roles, changes in society might follow "arresting the reproduction of systematic inequalities". ${ }^{77}$

The continuing inability or denial of law to recognise gendered difference is not to suggest, however, that we are "stuck" with law's expected gender performances. Arguably, there remains the possibility of a "space" which will allow some degree of resistance to the strictures of power. ${ }^{78}$ There are ways in which there might be potential for resistance to some of the hegemonic norms constructed by legal discourse through "resignification": "the site of radical reoccupation and resignification". Juridical power conceals the mechanism of its own productivity, thus;

Juridical power inevitably "produces" what it claims merely to represent. In effect, the Law produces and then conceals the notion of a "subject before the Law" in order to invoke that discursive formation as a naturalised foundational premise that subsequently legitimates law's own regulatory hegemony. ${ }^{79}$

During the course of this paper I have attempted to offer an alternative reading of conduct and behaviour as performatively constituted. If, as Butler argues, the subject is not formed once and for all, but it is continuously and repeatedly produced, there is the scope for legal discourse to re-evaluate what performances count when deciding upon proprietary interests. There is a need to place much greater focus upon the "use of language", to move away from a financial focus. ${ }^{80} \mathrm{I}$ am not suggesting that the ideas presented in this paper have the solution for the seemingly intractable problems of cohabitants' property disputes. However, the fact remains that, despite numerous attempts and what must amount to thousands of hours spent trying to solve the problem, no solution has been found and, at the time of writing, does not look likely to be found. Nevertheless, if there is one relatively uncontroversial statement that can be made, it is that reform is chronically urgently overdue. $^{81}$ Until law recognises the plurality of the learnt nature of gender and its performativity, the property interests of cohabitants will continue to be determined according to an inaccurate perception of identity formation and relationships meaning that the demands of justice and good conscience will continue to go unfulfilled.

\footnotetext{
76 J Butler, The Psychic Life of Power: Theories in subjection (Stanford: Stanford UP 1997), p. 104.

77 M T Talbot, Language and Gender: An introduction (Cambridge: Polity Press 1998), p. 15.

78 M Foucault, History of Sexuality vol. 1: An Introduction, R Hurley (trans.) (New York: Vintage/Random House 1980).

79 Butler, Gender Trouble, n. 11 above, p. 3.

80 Bottomley, "Self and subjectivities", n. 68 above, p. 61.

81 In fact, the need for reform has been "urgent" for some considerable amount of time. See, for example, Barlow and Lind, "A matter of trust", n. 42 above, p. 488.
} 